\title{
AN ALGORITHM TO SOLVE THE INVERSE KINEMATICS TO A
} STEWART PLATFORM

Florian Ion Tiberiu Petrescu Bucharest Polytechnic University, Romania

E-mail: petrescuflorian@yahoo.com

Relly Victoria Virgil Petrescu Bucharest Polytechnic University, Faculty of Transport, Romania E-mail:rvvpetrescu@gmail.com

Submission: 2/15/2018 Revision: 3/22/2018 Accept: 2/27/2019

\section{ABSTRACT}

Mechanical systems in motion type parallel structures are solid, fast and accurate. Between mobile systems parallel the best known and used system is that of a Stewart platform, as being and the oldest system, quickly, solid and accurate. The paper presents a few main elements of the Stewart platforms. In the case where a motto element consists of a structure composed of two elements in a relative movement from the point of view of the train of propulsion and especially in the dynamic calculations, it is more convenient to represent the motto element as a single moving item. The paper presents an exact, original analytical geometry method for determining the kinematic and dynamic parameters of a parallel mobile structure. Compared with other methods already known, the presented method has the great advantage of being an exact analytical method of calculation and not one iterative-approximately.

Keywords: An algorithm, Mechatronics, Robotics, Parallel moving mechanical systems, A Stewart structure 
ISSN: 2236-269X

DOI: 10.14807/ijmp.v11i2.788

\section{INTRODUCTION}

The humanoids robots are used now as a tool for research in several scientific fields.

Researchers need to understand the structure of the human body and behavior (biomechanics) to build and to study robots humanoids. On the other hand, the attempt simulation of the human body leads to a greater understanding of it. Human knowledge is a field of study, which is focused on the way in that people learn from sensory information in order to acquire the skills and insightful motor. Such knowledge is used to develop models for the calculation of human behavior and has been improved in time.

It has been suggested that robotics highly advanced will facilitate its increase even in ordinary people.

With all that the original purpose of humanoid research has been to build a better orthosis and prosthesis for human beings, knowledge has been transferred between the two disciplines. Some examples are Prosthesis footswitch with electrical adjustment for impaired neuromuscular, orthosis ankle-foot, biological realistic prosthesis leg and forearm prosthesis (AVERSA et al., 2017a; AVERSA et al., 2017b; AVERSA et al., 2016a; AVERSA et al., 2016b; AVERSA et al., 2016c; AVERSA et al., 2016d; CAO et al., 2013; DONG et al., 2013; GARCIA et al., 2007; GARCIA-MURILLO et al., 2013; GOUGHSTEWART PLATFORM; HE et al., 2013; LEE, 2013; LIN et al., 2013; LIU et al., 2013; MELO et al., 2012; MIRSAYAR et al., 2016; PADULA; PERDEREAU, 2013; PERUMAL; JAWAHAR, 2013; PETRESCU; PETRESCU, 2011, ; PETRESCU; PETRESCU, 2012, ; PETRESCU; PETRESCU, 2014, ; PETRESCU; PETRESCU, 2016a; PETRESCU; PETRESCU, 2016b; PETRESCU et al., 2016a; PETRESCU et al., 2016b; PETRESCU, 2012; REDDY et al., 2012; TABAKOVIĆ et al., 2013; TANG et al., 2013; TONG et al., 2013; WANG et al., 2013; WEN et al., 2012).

In addition to the research, robots humanoids are developed to perform human activities, such as personal assistance, where they would be able to help places of work diseased and the elderly and dirty or dangerous. Workplaces ordinary, such as to be a yacht or a worker of a production line of cars are also suitable for the humanoids." In essence, as they can use tools and operate the equipment and vehicles designed to human form, those humanoids could carry out, theoretically, any load a human being may, as long as they have the software itself. However, the complexity to do this is deceptively big.

They are also more popular for the provision of entertainment. For example, Ursula, 
DOI: 10.14807/ijmp.v11i2.788

food Sex Female, sing, play music, dances and speaks to the public her from Universal Studios. More highlights Disney hire the use of animatrons, robots that look, move and speak in the same way as human beings, in some thematic shows.

These animatrons look so realistic that it can be difficult to decipher the remote whether or not they are in fact they are human. Though they look realistic, they do not have yet any cognitive autonomy or natural. Various robots humanoids and possible their applications in everyday life are presented in a documentary film independently, called Plug and Pray, which has been launched in 2010.

Robots humanoids, in particular with the algorithms of artificial intelligence, could be useful for future dangerous mission and/or at a high distance for the spatial scan without the need to turn around again and to get back on the ground once the mission is completed.

A sensor is a device which measures some attribute of the world. As one of the three primitives of robotics (apart from the planning and control), detection plays an important role in the fault finding sequential paradigms.

Sensors can be classified on the basis of the physical process which works with or, depending on the type of metering information which they give that output.

Proprioceptive sensors sense the position, the orientation and speed of the rubber body of humanoid.

In addition, people do not use their own proprioceptive sensors (e.g., to the touch, muscular extension, limb position) to help with robots Humanoid orientation. Their uses accelerometers to measure the acceleration, from which the speed can be calculated by means of the integration; tilt sensors to measure the tilt; sensor of force placed on her arms and legs to measure the force of contact with the robot environment; position sensors, which indicates the actual robot position (from which the speed can be calculated by the derivation of the movement laws) or even the speed sensors.

The arrays tactels can be used to provide data on what has been reached. The shadow of the hand uses an array of 34 tactile arranged under the skin of polyurethane on each finger. Touch sensors also provide information about the forces and the torques transferred between the robot and the other objects.

The vision (view) refers to the processing of data in any way that uses the electromagnetic spectrum to produce an image. In the robots, humanoids are used to 
DOI: 10.14807/ijmp.v11i2.788

recognize the objects and determine their properties (They put the sensors to the works at more than in a similar way the eyes of human beings). Most robots humanoids use CCD cameras that the sensors.

Sensors allow sound robots humanoids to hear the speech and the sounds of the environment and to carry out the functions that the ears of the human being. Microphones are usually used for this task.

Actuators are the motors responsible for the movement in and of the robot.

Robots humanoids are constructed in such a way that they mimic the human body so that they can use the actuators which carried out the movements such as the muscles and joints, though with a different structure. To obtain the same effect as the human movement, robots humanoids use actuator in rotating main. They may be either electrical wiring, pneumatic, hydraulics, piezoelectric, ultrasound.

Actuators hydraulic and electrical have a behavior very rigid and may be made only to act in a manner consistent with the, through the use of strategies relatively complex for the control of the feedback. While the electrical components of the motor actuation using cored are more suited for high speed and low load, hydraulic works well at low speed and high load.

Elements of the piezoelectric actuator generate a movement with a large capacity of force when it is applied to the voltage. They can be used for positioning the ultra-fine and for generating and handling large forces or pressure in situations static and dynamic.

Elements of the actuator with ultrasound are designed to produce movements in an order micrometer at frequencies ultra-sound (over $20 \mathrm{kHz}$ ). They are useful for vibration control applications, positioning, and fast switching.

Elements of the pneumatic actuator operate based on the compressibility of the gas. As they are inflated, extend along the axis and how to deflate, contracts. In the case where an end is fixed, the other will move in a linear trajectory. These components are intended for low speed and low load/average. Between the components of the pneumatic actuator are cylinders the gaiter, motors pneumatic, stepper motors gauge and of the artificial muscles pneumatic.

In the planning and control, the essential difference between the humanoids and other types of robots (such as industrial), is the fact that the robot move must be human 
INDEPENDENT JOURNAL OF MANAGEMENT \& PRODUCTION (IJM\&P)

http://www.ijmp.jor.br

v. 11, n. 2, March-April 2020

ISSN: 2236-269X

DOI: 10.14807/ijmp.v11i2.788

consumption as it may be, using locomotion with feet, in particular, lever biped. Planning the ideal for the movements of the humanoids during the normal course should lead to minimize power consumption, as it happens in the human body. For this reason, the studies on the dynamics and control of these types of structures are becoming increasingly important.

The problem of walking and of the stabilization on the surface for the robots is of great importance. Maintenance of the center of gravity of the robot over the center of the camp in order to ensure a stable position can be chosen as an objective of the control. In order to maintain the dynamic balance during their walk and a robot needs information on the contact force and the movement to the actual and desired. The solution to this problem is based on a major concept, Zero Point Time (ZMP).

Another feature of the robots humanoids is that moves, gather information (using sensors) to "real world" and to interact with her. They do not remain as other manipulators robots who work in environments very structured. In order to enable the humanoids to move in complex environments, planning and control must focus on the detection of selfcollision, planning and the way of avoiding obstacles.

The humanoids have not yet some features of the human body. These include structures with the variable flexibility to provide a fuse (to the robot in itself and for the people) and redundancy movements, i.e., more degrees of freedom and availability task, therefore, at the level. With all that these features are desirable for the robots humanoids, they will bring more complexity and new problems of planning and control. The field of dealing with the control of the whole body with these problems and to address proper coordination of many degrees of freedom, for example in order to carry out more tasks simultaneously control, while in the following an order given priority.

Robotic screwing unit with automatic feeding of screws are automatic machines with anthropomorphic arms: extremely flexible in all aspects; they allow to screw on different planes and have a high reconversion factor. In case of change of product or mode of production, the arm can be used in the most diverse applications.

Anthropomorphic industrial robots have become the most prevalent and most used. They are most prevalent on the planet because they were very well put in place and are more easily designed, manufactured and implemented, compared to other types of robots and manipulators. The most common is the structure of with a base made up of three 
DOI: 10.14807/ijmp.v11i2.788

rotating elements, 3R. It is a mechanical structure, furniture, with three degrees of mobility, easy designed, with a high mobility and a large workspace. They are big advantages it has established itself in the world of industrial robots and was generalized.

Like all industrial robots and this anthropomorphic structure, it was launched in the auto industry, which commissioned and produced almost all modern industrial robots. The main advantages of a structure of this kind are great mobility, a wider working space, a good dynamic, fast-moving and acceptable accuracy for industrial operations daily conjunction with most common.

When it comes to reliability and stability excessive anthropomorphic structure can't cope the tasks, she successfully being replaced by parallel structures.

Today the moving mechanical systems are utilized in almost all vital sectors of humanity. The robots are able to process integrated circuits sizes micro and nano, on which the man they can be seen only with electron microscopy. Dyeing parts in toxic environments, working in chemical and radioactive environments or at depths and pressures at the deep bottom of huge oceans, or conquest of cosmic space and visiting some new exoplanets (PETRESCU et al., 2017a; PETRESCU et al., 2017b; ; PETRESCU et al., 2017c; PETRESCU et al., 2017d; PETRESCU et al., 2017e; PETRESCU et al., 2017f; PETRESCU et al., 2017g; PETRESCU et al., 2017h; PETRESCU et al., 2017i; PETRESCU et al., 2017j; PETRESCU et al., 2017k; PETRESCU et al., 2017l; PETRESCU et al., 2017lm; PETRESCU et al., 2017n; PETRESCU et al., 2017o; PETRESCU et al., 2017p; PETRESCU et al., 2017q; PETRESCU et al., 2017r; PETRESCU et al., 2017s; PETRESCU et al., 2017t; PETRESCU et al., 2017u; PETRESCU et al., 2017v; PETRESCU et al., 2017w; PETRESCU et al., 2017x; PETRESCU et al., 2017y; PETRESCU et al., 2017z; PETRESCU et al., 2017ab; PETRESCU et al., 2017ac; PETRESCU et al., 2017ad; PETRESCU et al., 2017ae), are with robots systems possible and were turned into from the dream in reality because of use of mechanical platforms sequential gearbox.

The man will be able to carry out its mission supreme, conqueror of new galaxies, because of mechanical systems sequential gear-box (robotics systems). Robots were developed and diversified, different aspects, but today, they start to be directed on two major categories: systems serial and parallel systems. Parallel systems are more solid but more difficult to designed and handled, and for this reason, the serial systems were those which have developed the most. In medical operations or radioactive environments are 
ISSN: $2236-269 X$

DOI: 10.14807/ijmp.v11i2.788

preferred mobile systems parallel, because of their high accuracy positioning.

Moving mechanical systems parallel structures are solid, fast and accurate. Mechanical systems in motion type parallel structures are solid, fast and accurate. Between mobile systems parallel the best known and used system is that of a Stewart platform, as being and the oldest system, quickly, solid and accurate.

A platform Gough-Stewart is a type of parallel robot which has six actuators prismatic, frequently winches electric or hydraulic actuators attached in pairs at three positions on the base plate of the platform, passing over the three mounting points on a top plate. The devices placed on the top plate can be moved in the six degrees of freedom in which it is possible that a body free-suspended to move. These are the three movements linear x, y, z (lateral, Longitudinal and vertical) and the three revolutions step, roller, \& yaw sensor. The terms "six axes" or "6-DOF" (degrees of freedom), the platform is also used, also "Synergy" (see below).

This specialized aspect of six Jack has been used for the first time by VE (Eric Gough) in the United Kingdom and has been operational in 1954, design later being made public in a document 1965 D Stewart on British Institute Engineers mechanics. Although the short title Stewart Platform is now used for this look Jack, it would be more appropriate to Eric Gough to call it a platform Gough/Stewart. To be more specific, the original platform Stewart has had a design slightly different. See references for more detailed at the end of this Article.

To ensure that movements are produced by a combination of movements of several collars, such a device is sometimes called a movement synergistic platform due to the synergy (reciprocal interaction between the manner in which the sockets are programmed. Because the device has six jacks, is often, also known as a hexapod (six feet). Trademark the name "hexapod" (through geodesic technology) was originally for platforms of Stewart used in machine tools. However, the term is now used for platforms of 6-jack outside the machine tool, since this simply means "six feet".

The paper presents a few main elements of the Stewart platforms. Begin with the study of geometric, kinematic elements of the system and then shall be presented and some elements of dynamics.

In the event that a structural motto element consists of two elements in a relative movement from a structural point of view, the drive train and especially the dynamic it is 
DOI: 10.14807/ijmp.v11i2.788

more convenient to represent the motto element as a single component mobile. In this way remain seven elements in movement (the six motto elements or feet, to which shall be added the mobile platform 7) and a fixed component. Kinematics of positions shall be determined by an original method of analytical geometry (Fig. 1). The study of mechanical solids is achieved by means of specific calculations.

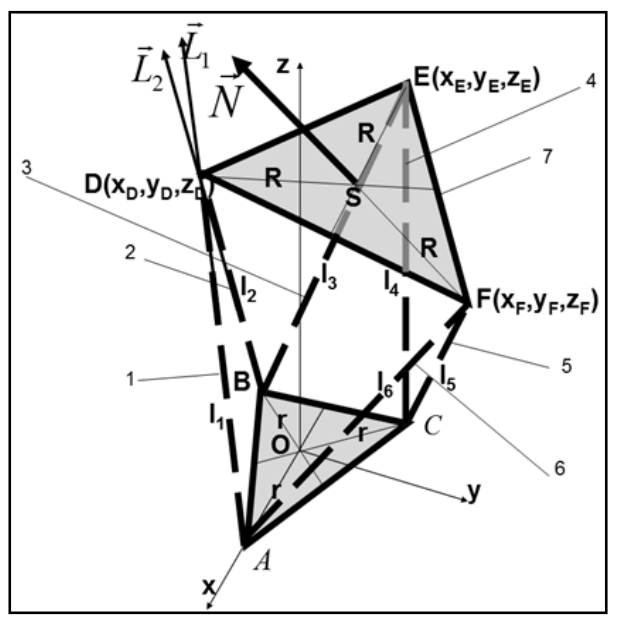

Figure 1: The structure and geometry of a Stewart platform

\section{MATERIALS AND METHODS: STRUCTURE AND GEOMETRY OF A STEWART PLATFORM}

An equilateral triangle in the lower and upper platform circles is used to simplify calculations. The base is the ABC (fixed) triangle with the xOyz fixed, rectangular axle system, and for the mobile (upper) platform, the DEF (mobile platform) triangle is adopted. The center of the fixed triangle is $\mathrm{O}$, and the mobile triangle is $\mathrm{S}$.

The reverse kinematics is much easier to determine, but it will still be studied for rational reasons, making it more logical to impose certain successive positions of the mobile platform (which it must occupy in turn) and, on their basis, determine the length of the six arms or legs corresponding to each position imposed in part.

In Figure 2 we determine the position parameters (spatial Cartesian coordinates) for fixed points A, B, C. For point A we obtain $\mathrm{x}=\mathrm{r}$ and $\mathrm{y}=\mathrm{z}=0$.

For point B the relations (1) are used, and the system (2) is considered for the determination of the coordinates of point $\mathrm{C}$. 
ISSN: 2236-269X

DOI: 10.14807/ijmp.v11i2.788

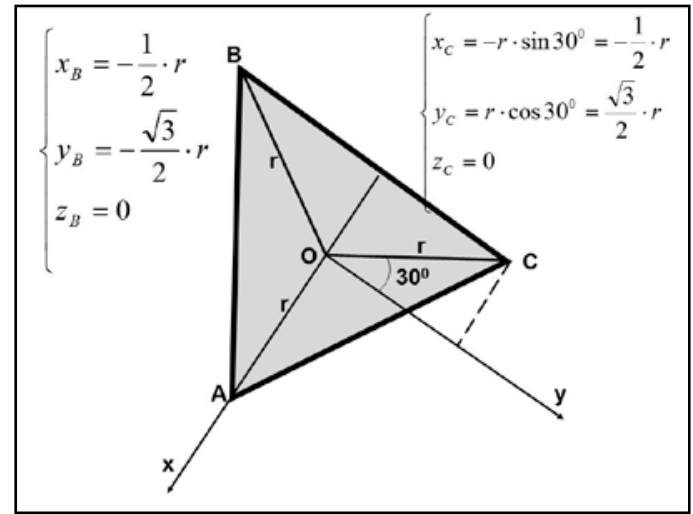

Figure 2: Base geometry (fixed plane) ABC

$\left\{\begin{array}{l}x_{B}=-\frac{1}{2} \cdot r \\ y_{B}=-\frac{\sqrt{3}}{2} \cdot r \\ z_{B}=0\end{array}\right.$

$\left\{\begin{array}{l}x_{C}=-r \cdot \sin 30^{\circ}=-\frac{1}{2} \cdot r \\ y_{C}=r \cdot \cos 30^{\circ}=\frac{\sqrt{3}}{2} \cdot r \\ z_{C}=0\end{array}\right.$

For the DEF mobile platform (see figure 3) the equations (3) can be written.

$$
\left\{\begin{array}{l}
\left\{\begin{array}{l}
\left(x_{D}-x_{S}\right)^{2}+\left(y_{D}-y_{S}\right)^{2}+\left(z_{D}-z_{S}\right)^{2}=R^{2} \\
\left(x_{D}-x_{S}\right) \cdot \alpha+\left(y_{D}-y_{S}\right) \cdot \beta+\left(z_{D}-z_{S}\right) \cdot \gamma=0
\end{array} \Rightarrow\right. \\
\Rightarrow\left\{\begin{array}{l}
y_{D}=y_{S}+\frac{\left(z_{S}-z_{D}\right) \cdot \beta \cdot \gamma+\alpha \cdot \sqrt{R^{2} \cdot\left(\alpha^{2}+\beta^{2}\right)-\left(z_{S}-z_{D}\right)^{2} \cdot\left(\alpha^{2}+\beta^{2}+\gamma^{2}\right)}}{\left(\alpha^{2}+\beta^{2}\right)} ; \text { for } \alpha \neq 0 \\
y_{D}=y_{S}+\left(z_{S}-z_{D}\right) \cdot \gamma+R ; \text { for } \alpha=0
\end{array}\right. \\
\Rightarrow x_{D}=x_{S}+\sqrt{R^{2}-\left(z_{D}-z_{S}\right)^{2}-\left(y_{D}-y_{S}\right)^{2}}
\end{array}\right.
$$




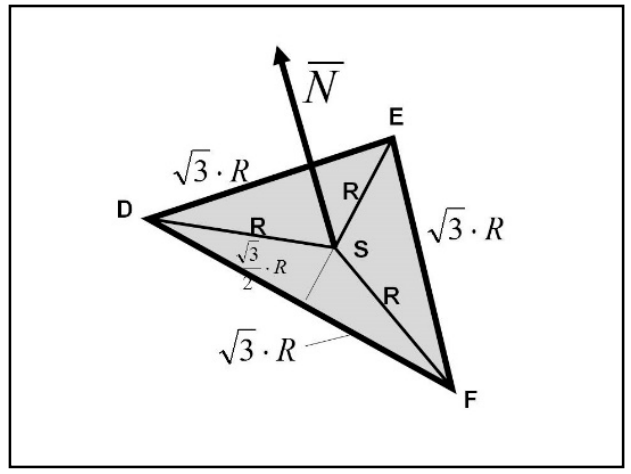

Figure 3: DEF mobile plan, geometry

It is determined the spatial coordinates of the point $\mathrm{D}$, when the height of this point is known, $\mathrm{h}$, ie the coordinate of the $\mathrm{z}_{\mathrm{D}}$, the radius $\mathrm{R}$ is known, all the coordinates of the central point $\mathrm{S}$ of the upper platform are known. We mention that all the coordinates of the points $\mathrm{A}$, $\mathrm{B}$ and $\mathrm{C}$ have already been determined and are already known.

The coordinates $\mathrm{x}$ and $\mathrm{y}$ of point $\mathrm{D}$ must be determined because $\mathrm{z}$ coordinate is already known. It solves the system formed by the first two equations and ultimately obtains the last two relationships that generate the solutions $\mathrm{YD}_{\mathrm{D}}$ and $\mathrm{X}_{\mathrm{D}}$. We basically use the equation of the sphere having the center in $\mathrm{S}$ and the radius $\mathrm{R}$ to reach point $\mathrm{D}$. However, we need the equation of the center circle $\mathrm{S}$ and the radius $\mathrm{R}$ that is inscribed in the plane of the mobile triangle. In order to obtain from the sphere a circle we intersect the sphere with the plane of the mobile triangle (PETRESCU; PETRESCU, 2014).

Two equations with three unknowns appear instead of an equation, but an unknown one disappears by intersecting our circle with the horizontal plane of height $h$ known, $h$ being the height at which the point $\mathrm{D}$ is to be found. In this way the two written equations will remain with only two unknowns, $\mathrm{x}_{\mathrm{D}}$ and $\mathrm{y}_{\mathrm{D}}$, since $\mathrm{z}_{\mathrm{D}}$ becomes known being identical to the height $\mathrm{h}$. The system of the two equations with two unknowns is solved and the values $\mathrm{y}_{\mathrm{D}}$ and $\mathrm{x}_{\mathrm{D}}$ are obtained respectively. For yd, two different situations are required, for which two different equations are used.

The general case when alpha is different from zero is solved with the equation obtained from the system, and the particular case in which alpha is equal to zero is solved using the same equation to which the boundaries have been applied and so the equation has changed its shape initially, losing the alpha value from the denominator. In the program, an if logical counter was used for these distinct situations. Next, the coordinates of points F and $\mathrm{E}$ are easily determined by an original rotation method (PETRESCU; PETRESCU, 2014) using equations 4 and 5. 
DOI: 10.14807/ijmp.v11i2.788

With the known coordinates of points D, E, F imposed by the position of the DEF plane and the choice of point $\mathrm{D}$, the necessary lengths of the legs (motor elements) are determined (see relations 6).

$$
\begin{aligned}
& \int x_{F}=x_{S}-\frac{1}{2} \cdot\left(x_{D}-x_{S}\right)+\frac{\sqrt{3}}{2} \cdot\left(y_{D}-y_{S}\right) \\
& \left\{y_{F}=y_{S}-\frac{1}{2} \cdot\left[\beta \cdot\left(z_{D}-z_{S}\right)-\gamma \cdot\left(y_{D}-y_{S}\right)\right]+\frac{\sqrt{3}}{2} \cdot\left[\gamma \cdot\left(x_{D}-x_{S}\right)-\alpha \cdot\left(z_{D}-z_{S}\right)\right]\right. \\
& Z_{F}=Z_{S}-\frac{1}{2} \cdot R \cdot \alpha+\frac{\sqrt{3}}{2} \cdot R \cdot \beta \\
& \left\{\begin{array}{l}
x_{E}=x_{S}-\frac{1}{2} \cdot\left(x_{D}-x_{S}\right)-\frac{\sqrt{3}}{2} \cdot\left(y_{D}-y_{S}\right) \\
y_{E}=y_{S}-\frac{1}{2} \cdot\left[\beta \cdot\left(z_{D}-z_{S}\right)-\gamma \cdot\left(y_{D}-y_{S}\right)\right]-\frac{\sqrt{3}}{2} \cdot\left[\gamma \cdot\left(x_{D}-x_{S}\right)-\alpha \cdot\left(z_{D}-z_{S}\right)\right]
\end{array}\right. \\
& Z_{E}=Z_{S}-\frac{1}{2} \cdot R \cdot \alpha-\frac{\sqrt{3}}{2} \cdot R \cdot \beta \\
& \left\{\begin{array}{l}
l_{1}=\sqrt{\left(x_{D}-x_{A}\right)^{2}+\left(y_{D}-y_{A}\right)^{2}+\left(z_{D}-z_{A}\right)^{2}} \\
l_{2}=\sqrt{\left(x_{D}-x_{B}\right)^{2}+\left(y_{D}-y_{B}\right)^{2}+\left(z_{D}-z_{B}\right)^{2}} \\
l_{3}=\sqrt{\left(x_{E}-x_{B}\right)^{2}+\left(y_{E}-y_{B}\right)^{2}+\left(z_{E}-z_{B}\right)^{2}} \\
l_{4}=\sqrt{\left(x_{E}-x_{C}\right)^{2}+\left(y_{E}-y_{C}\right)^{2}+\left(z_{E}-z_{C}\right)^{2}} \\
l_{5}=\sqrt{\left(x_{F}-x_{C}\right)^{2}+\left(y_{F}-y_{C}\right)^{2}+\left(z_{F}-z_{C}\right)^{2}} \\
l_{6}=\sqrt{\left(x_{F}-x_{A}\right)^{2}+\left(y_{F}-y_{A}\right)^{2}+\left(z_{F}-z_{A}\right)^{2}}
\end{array}\right.
\end{aligned}
$$

The computing program used (written in excel) will be presented in Appendix 1.

\section{RESULTS AND DISCUSSION}

One applied the computational relationships for some possible situations and the program worked correctly. If the input parameters are not correct, in the sense that they cannot be met by the Stewart platform, then the program will not work (relays in relationships will vehemently oppose unrealistic situations described by inappropriate input parameters). Table 1 shows two different cases. 
Table 1: Two different cases

\begin{tabular}{|c|c|c|c|c|c|}
\hline \multicolumn{3}{|c|}{ Calculation example 1.} & \multicolumn{3}{|c|}{ Calculation example 2.} \\
\hline & A & B & & A & B \\
\hline 7 & $\mathrm{~h}[\mathrm{~m}]$ & 1.3 & 7 & $\mathrm{~h}[\mathrm{~m}]$ & 1.276 \\
\hline 8 & $\mathrm{R}[\mathrm{m}]$ & 0.1 & 8 & $\mathrm{R}[\mathrm{m}]$ & 0.1 \\
\hline 9 & $\mathrm{x}_{\mathrm{S}}[\mathrm{m}]$ & 0 & 9 & $\mathrm{x}_{\mathrm{S}}[\mathrm{m}]$ & 0 \\
\hline 10 & $\mathrm{ys}_{\mathrm{s}}[\mathrm{m}]$ & 0 & 10 & $\mathrm{ys}_{\mathrm{s}}[\mathrm{m}]$ & 0 \\
\hline 11 & $\mathrm{z}_{\mathrm{S}}[\mathrm{m}]$ & 1.3 & 11 & $\mathrm{z}_{\mathrm{S}}[\mathrm{m}]$ & 1.3 \\
\hline 12 & $\mathrm{a}[]$ & 0 & 12 & $\mathrm{a}[]$ & 0.707 \\
\hline 13 & $\mathrm{~b}[]$ & 0 & 13 & $\mathrm{~b}[]$ & 0 \\
\hline 14 & $\mathrm{~g}[]$ & 1 & 14 & $\mathrm{~g}[]$ & 0.707 \\
\hline 15 & $\mathrm{zD}[\mathrm{m}]$ & 1.3 & 15 & $\mathrm{zD}[\mathrm{m}]$ & 1.276 \\
\hline 16 & $\mathrm{y}_{\mathrm{D}}[\mathrm{m}] \mathrm{a}=0$ & 0.1 & 16 & $\mathrm{y}_{\mathrm{D}}[\mathrm{m}] \mathrm{a}=0$ & 0.116667 \\
\hline 17 & $\mathrm{y}_{\mathrm{D}}[\mathrm{m}] \mathrm{a} \neq 0$ & \#DIV/0! & 17 & $\mathrm{y}_{\mathrm{D}}[\mathrm{m}] \mathrm{a} \neq 0$ & 0.094281 \\
\hline 18 & $\mathrm{y}_{\mathrm{D}}[\mathrm{m}]$ & 0.1 & 18 & $\mathrm{yD}_{\mathrm{D}}[\mathrm{m}]$ & 0.094281 \\
\hline 19 & $\mathrm{x}_{\mathrm{D}}[\mathrm{m}]$ & 0 & 19 & $\mathrm{x}_{\mathrm{D}}[\mathrm{m}]$ & 0.02357 \\
\hline 20 & $\mathrm{x}_{\mathrm{E}}[\mathrm{m}]$ & -0.0866 & 20 & $\mathrm{X}_{\mathrm{E}}[\mathrm{m}]$ & -0.09343 \\
\hline 21 & $\mathrm{y}_{\mathrm{E}}[\mathrm{m}]$ & 0.05 & 21 & $\mathrm{y}_{\mathrm{E}}[\mathrm{m}]$ & 0.004466 \\
\hline 22 & $\mathrm{Z}_{\mathrm{E}}[\mathrm{m}]$ & 1.3 & 22 & $\mathrm{z}_{\mathrm{E}}[\mathrm{m}]$ & 1.264645 \\
\hline 23 & $\mathrm{x}_{\mathrm{F}}[\mathrm{m}]$ & 0.086603 & 23 & $\mathrm{x}_{\mathrm{F}}[\mathrm{m}]$ & 0.069865 \\
\hline 24 & $\mathrm{y}_{\mathrm{F}}[\mathrm{m}]$ & 0.05 & 24 & $\mathrm{y}_{\mathrm{F}}[\mathrm{m}]$ & 0.004466 \\
\hline 25 & $\mathrm{Z}_{\mathrm{F}}[\mathrm{m}]$ & 1.3 & 25 & $\mathrm{z}_{\mathrm{F}}[\mathrm{m}]$ & 1.264645 \\
\hline 26 & $\mathrm{x}_{\mathrm{A}}[\mathrm{m}]$ & 0.1 & 26 & $\mathrm{x}_{\mathrm{A}}[\mathrm{m}]$ & 0.1 \\
\hline 27 & $\mathrm{y}_{\mathrm{A}}[\mathrm{m}]$ & 0 & 27 & $\mathrm{y}_{\mathrm{A}}[\mathrm{m}]$ & 0 \\
\hline 28 & $\mathrm{z}_{\mathrm{A}}[\mathrm{m}]$ & 0 & 28 & $\mathrm{z}_{\mathrm{A}}[\mathrm{m}]$ & 0 \\
\hline 29 & $\mathrm{x}_{\mathrm{B}}[\mathrm{m}]$ & $\begin{array}{l}-0.05 \\
\end{array}$ & 29 & $\mathrm{x}_{\mathrm{B}}[\mathrm{m}]$ & -0.05 \\
\hline 30 & $\mathrm{y}_{\mathrm{B}}[\mathrm{m}]$ & -0.086 & 30 & $\mathrm{y}_{\mathrm{B}}[\mathrm{m}]$ & -0.086 \\
\hline 31 & $\mathrm{Z}_{\mathrm{B}}[\mathrm{m}]$ & 0 & 31 & $\mathrm{z}_{\mathrm{B}}[\mathrm{m}]$ & 0 \\
\hline 32 & $\mathrm{x}_{\mathrm{C}}[\mathrm{m}]$ & -0.05 & 32 & $\mathrm{x}_{\mathrm{C}}[\mathrm{m}]$ & -0.05 \\
\hline 33 & $\mathrm{y}_{\mathrm{C}}[\mathrm{m}]$ & 0.086 & 33 & $\mathrm{y}_{\mathrm{C}}[\mathrm{m}]$ & 0.086 \\
\hline 34 & $\mathrm{z}_{\mathrm{C}}[\mathrm{m}]$ & 0 & 34 & $\mathrm{z}_{\mathrm{C}}[\mathrm{m}]$ & 0 \\
\hline 35 & $\mathrm{l}_{1}[\mathrm{~m}]$ & 1.307 & 35 & $\mathrm{l}_{1}[\mathrm{~m}]$ & 1.282 \\
\hline 36 & $\mathrm{l}_{2}[\mathrm{~m}]$ & 1.314 & 36 & $\mathrm{l}_{2}[\mathrm{~m}]$ & 1.291 \\
\hline 37 & $\mathrm{l}_{3}[\mathrm{~m}]$ & 1.307 & 37 & $\mathrm{l}_{3}[\mathrm{~m}]$ & 1.268 \\
\hline 38 & $\mathrm{l}_{4}[\mathrm{~m}]$ & 1.301 & 38 & $\mathrm{l}_{4}[\mathrm{~m}]$ & 1.268 \\
\hline 39 & $\mathrm{l}_{5}[\mathrm{~m}]$ & 1.307 & 39 & $\mathrm{l}_{5}[\mathrm{~m}]$ & 1.272 \\
\hline 40 & $1_{6}[\mathrm{~m}]$ & 1.301 & 40 & $\mathrm{l}_{6}[\mathrm{~m}]$ & 1.265 \\
\hline
\end{tabular}

This original algorithm and computing program (presented in the appendix) manages to greatly ease the designer's work on such difficult systems.

\section{APPLICATIONS}

In the 1800s, Augustin Louis Cauchy, a pioneer in mathematical analysis, studied the stiffness of an "articulated octahedron" which is the ancestor of the hexapod. In 1949, V. E. Gough advanced in research and built a parallel mechanism to test tires under different loads.

A few years later, in 1965, D. Stewart began using a variant of the hexapod for flight simulators. The robot he built will be renamed on his behalf the "Stewart Platform". Over the years, the hexapod has been improved by sever-al engineers such as K. Cappel, Mc Callion etc.

A platform Gough-Stewart is a type of parallel robot which has six actuators prismatic, frequently winches electric or hydraulic actuators attached in pairs at three positions on the 
DOI: 10.14807/ijmp.v11i2.788

base plate of the platform, passing over the three mounting points on a top plate (GoughStewart platform, from Wikipedia).

The devices placed on the top plate can be moved in the six degrees of freedom in which it is possible that a body free-suspended to move.

These are the three movements linear $\mathrm{x}, \mathrm{y}, \mathrm{z}$ (lateral, Longitudinal and vertical) and the three revolutions step, roller, \& yaw sensor. The terms "six axes" or "6-DOF" (degrees of freedom), the platform is also used, also "Synergy".

This specialized aspect of six Jack has been used for the first time by VE (Eric Gough) in the United Kingdom and has been operational in 1954, design later being made public in a document 1965 D Stewart on British Institute Engineers mechanics. Although the short title Stewart Platform is now used for this look Jack, it would be more appropriate to Eric Gough to call it a platform Gough/Stewart. To be more specific, the original platform Stewart has had a design slightly different.

To ensure that movements are produced by a combination of movements of several collars, such a device is sometimes called a movement synergistic platform due to the synergy (reciprocal interaction between the manner in which the sockets are programmed.

Because the device has six jacks, is often, also known as a hexapod (six feet). Trademark the name "hexapod" (through geodesic Technology) was originally for platforms of Stewart used in machine tools. However, the term is now used for platforms of 6-jack outside the machine tool, since this simply means "six feet".

The presented system may be useful in particular to the surgical robots which operate patients; those systems require a very high accuracy of positioning.

Such systems of high precision of positioning may be useful in particular for the future operations on the brain, heart, liver, kidneys, but also to prosthesis miscellaneous.

These platforms can position very accurately even some very large weights, such as to the modern telescope stationary.

The design of the Stewart platform is widely used in the simulation of the flight, in particular in the so-called flight simulator full for which there is a need for all 6 degrees of freedom. This application has been developed by Redifon, whose simulators offering has become available for Boeing 707, Douglas DC-8, South Aviation Caravelle, Canadair CL-44, Boeing 727, the Comet, Vickers Viscount, Vickers Vanguard, Convair CV-990, Lockheed 
DOI: 10.14807/ijmp.v11i2.788

C130 Hercules, Vickers VC10 and Fokker F-27 1962.

In this role, the payload is the pilot reply and a system of visual display, normally in the order of several channels, in order to show the visual scene out of the world the crew of the aircraft, which are trained. Weights in the case of the payload of a flight simulator full for an airplane of large transport may be up to about 15,000 kilograms.

Similar platforms are used in simulators, mounted can usually be found on the large meals $x-y$ driving position in order to simulate the acceleration on a short-term basis acceleration in the long term, can be simulated by tilting the platform and an area of active research is how to mix the two.

Eric Gough has been an engineer auto and has worked at the Redoubt Dunlop, factory Dunlop tires of the Birmingham, England. He developed or "Universal Tir-Testare Machine" (also called "Universal Rig") and in 1950 and the platform was operational in 1954. The device has been able to mechanically tires tested in accordance with the combined tasks. Dr. Gough died in 1972, but the testing of its platform continued to be used up to the end of 1980 when the factory was closed and then demolished. His rig has been saved and transported to the marginal storage Science Museum (London), at Wrought on near Swindon.

The AMiBA radio telescope, a Cosmic Microwave Background experiment, is mounted on a $6 \mathrm{~m}$ carbon fiber hexapod. A hexapod robot is a walker robot whose locomotion is based on three pairs of legs. The study of the progress of insects is of particular interest to present an alternative to the use of wheels. The term thus refers to robots of biological inspiration imitating in the present case hexapod animals such as insects.

Hexapod robots are considered more stable than biped robots because in most cases hexapods are statically stable. Because of this, they do not depend on real-time controllers to stand or walk. However, it has been shown that at high displacement rates, insects are dependent on dynamic factors.

Insects were chosen as models because their nervous system is simpler than that of other animal species.

In addition, complex behaviors can be attributed to only a few neurons and the path between sensory inputs and motor outputs is relatively short.

The walking behavior of the insect and the neural architecture are used to improve the locomotion of the robot. Conversely, biologists use hexapod robots to test different hypotheses. 
ISSN: $2236-269 X$

DOI: 10.14807/ijmp.v11i2.788

\section{CONCLUSIONS}

The paper presents an exact, original analytical geometry method for determining the kinematic and dynamic parameters of a parallel mobile structure.

Compared with other methods already known, the presented method has the great advantage of being an exact analytical method of calculation and not one iterativeapproximately.

\section{FUNDING INFORMATION}

Research contract: Contract number 36-5-4D/1986 from 24IV1985, beneficiary CNST RO (Romanian National Center for Science and Technology) Improving dynamic mechanisms.

Contract research integration. 19-91-3 from 29.03.1991; Beneficiary: MIS; TOPIC: Research on designing mechanisms with bars, cams, and gears, with application in industrial robots.

Contract research. GR 69/10.05.2007: NURC in 2762; theme 8: Dynamic analysis of mechanisms and manipulators with bars and gears.

4-Labor contract, no. 35/22.01.2013, the UPB, "Stand for reading performance parameters of kinematics and dynamic mechanisms, using inductive and incremental encoders, to a Mitsubishi Mechatronic System" "PN-II-IN-CI-2012-1-0389".

All these matters are copyrighted! Copyrights: 394-qodGnhhtej, from 17-02-2010 13:42:18; 463-vpstuCGsiy, from 20-03-2010 12:45:30; 631-sqfsgqvutm, from 24-05-2010 16:15:22; 933-CrDztEfqow, from 07-01-2011 13:37:52.

\section{REFERENCES}

AVERSA, R.; PARCESEPE, D.; PETRESCU, R. V.; BERTO, F.; CHEN, G.; PETRESCU, F. I. T.; TAMBURRINO, F.; APICELLA, A. (2017a) Processability of Bulk Metallic Glasses. Am. J. Applied Sci., v. 14, n. 2, p. 294-301. DOI: 10.3844/ajassp.2017.294.301

AVERSA, R.; PETRESCU, R. V.; PETRESCU, F. I. T.; APICELLA, A. (2017b) NanoDiamond Hybrid Materials for Structural Biomedical Application. Am. J. of Biochemistry and Biotechnology, v. 13, n. 1, p. 34-41. DOI: 10.3844/ajbbsp.2017.34.41

AVERSA, R.; PARCESEPE, D.; PETRESCU, R. V.; CHEN, G.; PETRESCU, F. I. T.; TAMBURRINO, F.; APICELLA, A. (2016a) Glassy Amorphous Metal Injection Molded Induced Morphological Defects. Am. J. Applied Sci.,v. 13, n. 12, p. 1476-1482. DOI: 10.3844/ajassp.2016.1476.1482

AVERSA, R.; PETRESCU, F. I. T.; PETRESCU, R. V.; APICELLA, A. (2016b) Biomimetic Finite Element Analysis Bone Modeling for Customized Hybrid Biological Prostheses 
DOI: 10.14807/ijmp.v11i2.788

Development. Am. J. Applied Sci., v. 13, n. 11, p. 1060-1067. DOI: 10.3844/ajassp.2016.1060.1067

AVERSA, R.; TAMBURRINO, F.; PETRESCU, R. V.; PETRESCU, F. I. T.; ARTUR, M.; CHEN, G.; APICELLA, A. (2016c) Biomechanically Inspired Shape Memory Effect Machines Driven by Muscle like Acting NiTi Alloys. Am. J. Applied Sci., v. 13, n. 11, p. 1264-1271. DOI: 10.3844/ajassp.2016.1264.1271

AVERSA, R.; PETRESCU, R. V.; PETRESCU, F. I. T.; APICELLA, A. (2016d) SmartFactory: Optimization and Process Control of Composite Centrifuged Pipes. Am. J. Applied Sci., v. 13, n. 11, p. 1330-1341. DOI: 10.3844/ajassp.2016.1330.1341

CAO, W.; DING, H.; BIN, Z.; ZIMING, C. (2013) New structural representation and digitalanalysis platform for symmetrical parallel mechanisms. Int. J. Advanced Robotic Sys., DOI: $10.5772 / 56380$

DONG, H.; GIAKOUMIDIS, N.; FIGUEROA, N.; MAVRIDIS, N. (2013) Approaching behavior monitor and vibration indication in developing a General Moving Object Alarm System , n. GMOAS). Int. J. Advanced Robotic Sys., DOI: 10.5772/56586

GARCIA, E.; JIMENEZ, M. A.; DE SANTOS, P. G.; ARMADA, M. (2007) The evolution of robotics research. Robotics Automation Magazine, IEEE, n. 14, p. 90-103.

GARCIA-MURILLO, M.; GALLARDO-ALVARADO, J.; CASTILLO-CASTANEDA, E. (2013) Finding the generalized forces of a series-parallel manipulator. IJARS, DOI: $10.5772 / 53824$

GOUGH-STEWART PLATFORM, From Wikipedia, the free encyclopedia. Retrieved from: https://en.wikipedia.org/wiki/Stewart_platform

HE, B.; WANG, Z.; LI, Q.; XIE, H.; AND SHEN, R. (2013) An analytic method for the kinematics and dynamics of a multiple-backbone continuum robot. IJARS, DOI: $10.5772 / 54051$

LEE, B. J. (2013) Geometrical derivation of differential kinematics to calibrate model parameters of flexible manipulator. Int. J. Advanced Robotic Sys., DOI: 10.5772/55592

LIN, W.; LI, B.; YANG, X.; ZHANG, D. (2013) Modelling and control of inverse dynamics for a 5-DOF parallel kinematic polishing machine. Int. J. Advanced Robotic Sys., DOI: $10.5772 / 54966$

LIU, H.; ZHOU, W.; LAI, X.; ZHU, S. (2013) An efficient inverse kinematic algorithm for a PUMA560-structured robot manipulator. IJARS, DOI: 10.5772/56403

MELO, L. F.; REIS ALVES, S. F.; ROSARIO, J. M. (2012) Mobile robot navigation modelling, control and applications. Int. Rev. Modelling Simulations, n. 5, p. 1059-1068.

MIRSAYAR, M. M.; JONEIDI, V. A.; PETRESCU, R. V.; PETRESCU, F. I. T.; BERTO, F. (2017) Extended MTSN criterion for fracture analysis of soda lime glass, Engineering

Fracture Mechanics, v. 178, p. 50-59, ISSN: 0013-7944,

http://doi.org/10.1016/j.engfracmech.2017.04.018

PADULA, F.; PERDEREAU, V. (2013) An on-line path planner for industrial manipulators. Int. J. Advanced Robotic Sys.; DOI: 10.5772/55063

PERUMAL, S.; JAWAHAR, N. (2013) Automated trajectory planner of industrial robot for pick-and-place task. IJARS, DOI: 10.5772/53940 
PETRESCU, F. I. T. ; PETRESCU, R.V. (2011) Mechanical Systems, Serial and Parallel Course , n. in Romanian), LULU Publisher, London, UK, 124 pages, ISBN 978-1-44660039-9, Romanian edition.

PETRESCU, F. I. T.; PETRESCU, R. V. (2012) Mecatronica-sisteme seriale si paralele. Create Space publisher, USA, ISBN 978-1-4750-6613-5, 128 pages, Romanian edition.

PETRESCU, F. I. T.; APICELLA, A.; RAFFAELLA, A.; PETRESCU, R. V.; CALAUTIT, J. K.; MIRSAYAR, M. M.; ANIELLO, R. (2016b) Something about the Mechanical Moment of Inertia. Am. J. Applied Sci., v. 13, n. 11, p. 1085-1090. DOI:

10.3844/ajassp.2016.1085.1090

PETRESCU, F. I. T.; PETRESCU, R. V. (2016a) Parallel moving mechanical systems kinematics. ENGEVISTA, n. 18, p. 455-491.

PETRESCU, F. I. T.; PETRESCU, R. V. (2016b) Dynamic cinematic to a structure 2R. Revista Geintec-Gestao Inovacao E Tecnologias, n. 6, p. 3143-3154.

PETRESCU, F. I. T.; PETRESCU, R. V. (2014) Parallel Moving Mechanical Systems, IJM\&P, v. 5, n. 3, p. 564-580.

PETRESCU, F. I. T. (2012) Teoria Mecanismelor Color: Curs si Aplicatii. 1st Edn.; CreateSpace Publisher, p. 284.

PETRESCU, R. V.; AVERSA, R.; APICELLA, A.; PETRESCU, F. I. T. (2016A) Future medicine services robotics. Am. J. Eng. Applied Sci., n. 9, p. 1062-1087.

PETRESCU, R. V.; AVERSA, R.; AKASH, B.; BUCINELL, R.; CORCHADO, J. (2017a) Modern propulsions for aerospace-a review. J. Aircraft Spacecraft Technol., n. 1, p. 1-8. DOI: 10.3844 jastsp.2017.1.8

PETRESCU, R.V.; AVERSA, R.; AKASH, B.; BUCINELL, R.; CORCHADO, J. (2017b) Modern propulsions for aerospace-part II. J. Aircraft Spacecraft Technol., n. 1, p. 9-17. DOI: $10.3844 /$ jastsp.2017.9.17

PETRESCU, R.V.; AVERSA, R.; AKASH, B.; BUCINELL, R.; CORCHADO, J. (2017C) History of aviation-a short review. J. Aircraft Spacecraft Technol., n. 1, p. 30-49. DOI: 10.3844/jastsp.2017.30.49

PETRESCU, R.V.; AVERSA, R.; AKASH, B.; BUCINELL, R.; CORCHADO, J. (2017d) Lockheed martin-a short review. J. Aircraft Spacecraft Technol., n. 1, p. 50-68. DOI: 10.3844/jastsp.2017.50.68

PETRESCU, R. V.; AVERSA, R.; AKASH, B.; CORCHADO, J.; BERTO, F. (2017e) Our universe. J. Aircraft Spacecraft Technol., n. 1, p. 69-79. DOI: 10.3844/jastsp.2017.69.79

PETRESCU, R. V.; AVERSA, R.; AKASH, B.; CORCHADO, J.; BERTO, F. (2017f) What is a UFO? J. Aircraft Spacecraft Technol., n. 1, p. 80-90. DOI: 10.3844/jastsp.2017.80.90

PETRESCU, R. V.; AVERSA, R.; AKASH, B.; CORCHADO, J.; BERTO, F. (2017g) About bell helicopter FCX-001 concept aircraft-a short review. J. Aircraft Spacecraft Technol., n. 1, p. 91-96. DOI: 10.3844/jastsp.2017.91.96

PETRESCU, R. V.; AVERSA, R.; AKASH, B.; CORCHADO, J.; BERTO, F. (2017h) Home at airbus. J. Aircraft Spacecraft Technol., n. 1, p. 97-118. DOI:

10.3844/jastsp.2017.97.118 
PETRESCU, R. V.; AVERSA, R.; AKASH, B.; CORCHADO, J.; BERTO, F. (2017i) Airlander. J. Aircraft Spacecraft Technol., n. 1, p. 119-148. DOI: 10.3844/jastsp.2017.119.148

PETRESCU, R. V.; AVERSA, R.; AKASH, B.; CORCHADO, J.; BERTO, F. (2017j) When boeing is dreaming-a review. J. Aircraft Spacecraft Technol., n. 1, p. 149-161. DOI: 10.3844/jastsp.2017.149.161

PETRESCU, R. V.; AVERSA, R.; AKASH, B.; CORCHADO, J.; BERTO, F. (2017k) About Northrop Grumman. J. Aircraft Spacecraft Technol., n. 1, p. 162-185. DOI: 10.3844/jastsp.2017.162.185

PETRESCU, R. V.; AVERSA, R.; AKASH, B.; CORCHADO, J.; BERTO, F. (2017l) Some special aircraft. J. Aircraft Spacecraft Technol., n. 1, p. 186-203. DOI:

10.3844/jastsp.2017.186.203

PETRESCU, R. V.; AVERSA, R.; AKASH, B.; CORCHADO, J.; BERTO, F. (2017m) About helicopters. J. Aircraft Spacecraft Technol., n. 1, p. 204-223. DOI: 10.3844/jastsp.2017.204.223

PETRESCU, R. V.; AVERSA, R.; AKASH, B.; BERTO, F.; APICELLA, A. (2017n) The modern flight. J. Aircraft Spacecraft Technol., n. 1, p. 224-233. DOI: 10.3844/jastsp.2017.224.233

PETRESCU, R. V.; AVERSA, R.; AKASH, B.; BERTO, F.; APICELLA, A. (2017o) Sustainable energy for aerospace vessels. J. Aircraft Spacecraft Technol., n. 1, p. 234-240. DOI: $10.3844 /$ jastsp.2017.234.240

PETRESCU, R. V.; AVERSA, R.; AKASH, B.; BERTO, F.; APICELLA, A. (2017p)

Unmanned helicopters. J. Aircraft Spacecraft Technol., n. 1, p. 241-248. DOI: 10.3844/jastsp.2017.241.248

PETRESCU, R. V.; AVERSA, R.; AKASH, B.; BERTO, F.; APICELLA, A. (2017q) Project HARP. J. Aircraft Spacecraft Technol., n. 1, p. 249-257. DOI: 10.3844/jastsp.2017.249.257

PETRESCU, R. V.; AVERSA, R.; AKASH, B.; BERTO, F.; APICELLA, A. (2017r)

Presentation of romanian engineers who contributed to the development of global aeronautics-part I. J. Aircraft Spacecraft Technol., n. 1, p. 258-271. DOI: 10.3844/jastsp.2017.258.271

PETRESCU, R. V.; AVERSA, R.; AKASH, B.; BERTO, F.; APICELLA, A. (2017s) A firstclass ticket to the planet mars, please. J. Aircraft Spacecraft Technol., n. 1, p. 272-281. DOI: 10.3844 /jastsp.2017.272.281

PETRESCU, R. V.; AVERSA, R.; AKASH, B.; BERTO, F.; APICELLA, A.; PETRESCU, F. I. T. (2017t) Forces of a 3R Robot. J. of Mechatronics and Robotics, v. 1, n. 1, p. 1-14. DOI: $10.3844 /$ jmrsp.2017.1.14

PETRESCU, R. V.; AVERSA, R.; AKASH, B.; BERTO, F.; APICELLA, A.; PETRESCU, F. I. T. (2017u) Direct Geometry and Cinematic to the MP-3R Systems. J. of Mechatronics and Robotics, v. 1, n. 1, p. 15-23. DOI: 10.3844/jmrsp.2017.15.23

PETRESCU, R. V.; AVERSA, R.; AKASH, B.; BERTO, F.; APICELLA, A.; PETRESCU, F. I. T. (2017v. Dynamic Elements at MP3R. J. of Mechatronics and Robotics 1, n. 2, p. 24-37. DOI: 10.3844/jmrsp.2017.24.37 
PETRESCU, R. V.; AVERSA, R.; AKASH, B.; BERTO, F.; APICELLA, A.; PETRESCU, F. I. T. (2017w) Geometry and Direct Kinematics to MP3R with 4×4 Operators. J. of Mechatronics and Robotics, v. 1, n. 2, p. 38-46. DOI: 10.3844/jmrsp.2017.38.46

PETRESCU, R. V.; AVERSA, R.; APICELLA, A.; MIRSAYAR, M. M.; KOZAITIS, S.; ABU-LEBDEH, T.; PETRESCU, F. I. T. (2017x) Current Stage in the Field of Mechanisms with Gears and Rods. J. of Mechatronics and Robotics, v. 1, n. 2, p. 47-57. DOI: 10.3844/jmrsp.2017.47.57

PETRESCU, R. V.; AVERSA, R.; APICELLA, A.; MIRSAYAR, M. M.; KOZAITIS, S.; ABU-LEBDEH, T.; PETRESCU, F. I. T. (2017y) Geometry and Inverse Kinematic at the MP3R Mobile Systems. J. of Mechatronics and Robotics, v. 1, n. 2, p. 58-65. DOI: 10.3844/jmrsp.2017.58.65

PETRESCU, R. V.; AVERSA, R.; APICELLA, A.; MIRSAYAR, M. M.; KOZAITIS, S.; ABU-LEBDEH, T.; PETRESCU, F. I. T. (2017z) Synthesis of Optimal Trajectories with Functions Control at the Level of the Kinematic Drive Couplings. J. of Mechatronics and Robotics, v. 1, n. 2, p. 66-74. DOI: 10.3844/jmrsp.2017.66.74

PETRESCU, R. V.; AVERSA, R.; APICELLA, A.; MIRSAYAR, M. M.; KOZAITIS, S.; ABU-LEBDEH, T.; PETRESCU, F. I. T. (2017aa) The Inverse Kinematics of the Plane System 2-3 in a Mechatronic MP2R System, by a Trigonometric Method. J. of Mechatronics and Robotics, v. 1, n. 2, p. 75-87. DOI: 10.3844/jmrsp.2017.75.87

PETRESCU, R. V.; AVERSA, R.; APICELLA, A.; MIRSAYAR, M. M.; KOZAITIS, S.; ABU-LEBDEH, T.; PETRESCU, F. I. T. (2017ab) Serial, Anthropomorphic, Spatial, Mechatronic Systems can be Studied More Simply in a Plan. J. of Mechatronics and Robotics, v. 1, n. 2, p. 88-97. DOI: 10.3844/jmrsp.2017.88.97

PETRESCU, R. V.; AVERSA, R.; APICELLA, A.; MIRSAYAR, M. M.; KOZAITIS, S.; ABU-LEBDEH, T.; PETRESCU, F. I. T. (2017ac) Analysis and Synthesis of Mechanisms with Bars and Gears Used in Robots and Manipulators. J. of Mechatronics and Robotics, v. 1, n. 2, p. 98-108. DOI: 10.3844/jmrsp.2017.98.108

PETRESCU, R. V.; AVERSA, R.; APICELLA, A.; MIRSAYAR, M. M.; KOZAITIS, S.; ABU-LEBDEH, T.; PETRESCU, F. I. T. (2017ad) Speeds and Accelerations in Direct Kinematics to the MP3R Systems. J. of Mechatronics and Robotics, v. 1, n. 2, p. 109-117. DOI: $10.3844 /$ jmrsp.2017.109.117

PETRESCU, R. V.; AVERSA, R.; APICELLA, A.; MIRSAYAR, M. M.; KOZAITIS, S.; ABU-LEBDEH, T.; PETRESCU, F. I. T. (2017ae) Geometry and Determining the Positions of a Plan Transporter Manipulator. J. of Mechatronics and Robotics, v. 1, n. 2, p. 118-126. DOI: $10.3844 /$ jmrsp.2017.118.126

REDDY, P.; SHIHABUDHEEN, K. V.; JACOB, J. (2012) Precise nonlinear modeling of flexible link flexible joint manipulator. IReMoS, n. 5, p. 1368-1374.

TABAKOVIĆ, S.; ZELJKOVIĆ, M.; GATALO, R.; ŽIVKOVIĆ, A. (2013) Program suite for conceptual designing of parallel mechanism-based robots and machine tools. Int. J.

Advanced Robotic Sys.; DOI: 10.5772/56633

TANG, X.; SUN, D.; SHAO, Z. (2013) The structure and dimensional design of a reconfigurable PKM. IJARS, DOI: 10.5772/54696

TONG, G.; GU, J.; XIE, W. (2013) Virtual entity-based rapid prototype for design and simulation of humanoid robots. Int. J. Advanced Robotic Sys.; DOI: 10.5772/55936 
ISSN: 2236-269X

DOI: 10.14807/ijmp.v11i2.788

WANG, K.; LUO, M.; MEI, T.; ZHAO, J.; CAO, Y. (2013) Dynamics analysis of a threeDOF planar serial-parallel mechanism for active dynamic balancing with respect to a given trajectory. Int. J. Advanced Robotic Sys.; DOI: 10.5772/54201

WEN, S.; ZHU, J.; LI, X.; RAD, A.; CHEN, X. (2012) End-point contact force control with quantitative feedback theory for mobile robots. IJARS, DOI: $10.5772 / 53742$

\section{Appendix}

\begin{tabular}{|c|c|c|}
\hline & & Calculation program \\
\hline & A & B \\
\hline 7 & $\mathrm{~h}[\mathrm{~m}]$ & $=1.3$ \\
\hline 8 & $\mathrm{R}[\mathrm{m}]$ & 0.1 \\
\hline 9 & $\mathrm{xS}[\mathrm{m}]$ & 0 \\
\hline 10 & $\mathrm{yS}[\mathrm{m}]$ & 0 \\
\hline 11 & $\mathrm{zS}[\mathrm{m}]$ & 1.3 \\
\hline 12 & $\square[]$ & 0 \\
\hline 13 & $\square[]$ & 0 \\
\hline 14 & $\square[]$ & 1 \\
\hline 15 & $\mathrm{zD}[\mathrm{m}]$ & $=\mathrm{B} 7$ \\
\hline 16 & $\mathrm{yD}[\mathrm{m}] \mathrm{a}=0$ & $=\mathrm{B} 10+(\mathrm{B} 11-\mathrm{B} 15) * \mathrm{~B} 14+\mathrm{B} 8$ \\
\hline 17 & $\mathrm{yD}[\mathrm{m}] \mathrm{a} \neq 0$ & $\begin{array}{l}=\mathrm{B} 10+\left((\mathrm{B} 11-\mathrm{B} 15) * \mathrm{~B} 13^{*} \mathrm{~B} 14+\mathrm{B} 12^{*} \mathrm{SQRT}\left(\mathrm{B} 8 \wedge 2^{*}\left(\mathrm{~B} 12^{\wedge} 2+\mathrm{B} 13^{\wedge} 2\right)-(\mathrm{B} 11-\right.\right. \\
\left.\left.\mathrm{B} 15)^{\wedge} 2^{*}\left(\mathrm{~B} 12^{\wedge} 2+\mathrm{B} 13^{\wedge} 2+\mathrm{B} 14 \wedge 2\right)\right)\right) /\left(\mathrm{B} 12^{\wedge} 2+\mathrm{B} 13^{\wedge} 2\right)\end{array}$ \\
\hline 18 & $\mathrm{yD}[\mathrm{m}]$ & $=\mathrm{IF}(\mathrm{B} 12=0, \mathrm{~B} 16, \mathrm{~B} 17)$ \\
\hline 19 & $\mathrm{xD}[\mathrm{m}]$ & $=\mathrm{B} 9+\mathrm{SQRT}\left(\mathrm{B} 8 \wedge 2-(\mathrm{B} 15-\mathrm{B} 11)^{\wedge} 2-(\mathrm{B} 18-\mathrm{B} 10)^{\wedge} 2\right)$ \\
\hline 20 & $\mathrm{xE}[\mathrm{m}]$ & $=$ B9-1/2*(B19-B9)-SQRT(3)/2*(B18-B10) \\
\hline 21 & $\mathrm{yE}[\mathrm{m}]$ & $\begin{array}{l}=\mathrm{B} 10-1 / 2 *(\mathrm{~B} 13 *(\mathrm{~B} 15-\mathrm{B} 11)-\mathrm{B} 14 *(\mathrm{~B} 18-\mathrm{B} 10))-\mathrm{SQRT}(3) / 2 *(\mathrm{~B} 14 *(\mathrm{~B} 19-\mathrm{B} 9)- \\
\mathrm{B} 12 *(\mathrm{~B} 15-\mathrm{B} 11))\end{array}$ \\
\hline 22 & $\mathrm{zE}[\mathrm{m}]$ & $=\mathrm{B} 11-1 / 2 * \mathrm{~B} 8 * \mathrm{~B} 12-\mathrm{SQRT}(3) / 2 * \mathrm{~B} 8 * \mathrm{~B} 13$ \\
\hline 23 & $\mathrm{xF}[\mathrm{m}]$ & $=\mathrm{B} 9-1 / 2 *(\mathrm{~B} 19-\mathrm{B} 9)+\mathrm{SQRT}(3) / 2 *(\mathrm{~B} 18-\mathrm{B} 10)$ \\
\hline 24 & $\mathrm{yF}[\mathrm{m}]$ & $\begin{array}{l}=\mathrm{B} 10-1 / 2 *(\mathrm{~B} 13 *(\mathrm{~B} 15-\mathrm{B} 11)-\mathrm{B} 14 *(\mathrm{~B} 18-\mathrm{B} 10))-\mathrm{SQRT}(3) / 2 *(\mathrm{~B} 14 *(\mathrm{~B} 19-\mathrm{B} 9)- \\
\mathrm{B} 12 *(\mathrm{~B} 15-\mathrm{B} 11))\end{array}$ \\
\hline 25 & $\mathrm{zF}[\mathrm{m}]$ & $=\mathrm{B} 11-1 / 2 * \mathrm{~B} 8 * \mathrm{~B} 12+\mathrm{SQRT}(3) / 2 * \mathrm{~B} 8 * \mathrm{~B} 13$ \\
\hline 26 & $\mathrm{xA}[\mathrm{m}]$ & $=\mathrm{B} 8$ \\
\hline 27 & $\mathrm{yA}[\mathrm{m}]$ & $=0$ \\
\hline 28 & $\mathrm{zA}[\mathrm{m}]$ & $=0$ \\
\hline 29 & $\mathrm{xB}[\mathrm{m}]$ & $=-1 / 2 * \mathrm{~B} 8$ \\
\hline 30 & $\mathrm{yB}[\mathrm{m}]$ & $=-\mathrm{SQRT}(3) / 2 * \mathrm{~B} 8$ \\
\hline 31 & $\mathrm{zB}[\mathrm{m}]$ & $=0$ \\
\hline 32 & $\mathrm{xC}[\mathrm{m}]$ & $=-1 / 2 * \mathrm{~B} 8$ \\
\hline 33 & $\mathrm{yC}[\mathrm{m}]$ & $=\mathrm{SQRT}(3) / 2 * \mathrm{~B} 8$ \\
\hline 34 & $\mathrm{zC}[\mathrm{m}]$ & $=0$ \\
\hline 35 & $11[\mathrm{~m}]$ & $=\mathrm{SQRT}\left((\mathrm{B} 19-\mathrm{B} 26)^{\wedge} 2+(\mathrm{B} 18-\mathrm{B} 27)^{\wedge} 2+(\mathrm{B} 15-\mathrm{B} 28)^{\wedge} 2\right)$ \\
\hline 36 & $12[\mathrm{~m}]$ & $=\mathrm{SQRT}\left((\mathrm{B} 19-\mathrm{B} 29)^{\wedge} 2+(\mathrm{B} 18-\mathrm{B} 30)^{\wedge} 2+(\mathrm{B} 15-\mathrm{B} 31)^{\wedge} 2\right)$ \\
\hline 37 & $13[\mathrm{~m}]$ & $=\mathrm{SQRT}\left((\mathrm{B} 20-\mathrm{B} 29)^{\wedge} \wedge+(\mathrm{B} 21-\mathrm{B} 30)^{\wedge} 2+(\mathrm{B} 22-\mathrm{B} 31)^{\wedge} 2\right)$ \\
\hline 38 & $14[\mathrm{~m}]$ & $=\mathrm{SQRT}\left((\mathrm{B} 20-\mathrm{B} 32)^{\wedge} 2+(\mathrm{B} 21-\mathrm{B} 33)^{\wedge} 2+(\mathrm{B} 22-\mathrm{B} 34)^{\wedge} 2\right)$ \\
\hline 39 & $15[\mathrm{~m}]$ & $=\mathrm{SQRT}\left((\mathrm{B} 23-\mathrm{B} 32)^{\wedge} 2+(\mathrm{B} 24-\mathrm{B} 33)^{\wedge} 2+(\mathrm{B} 25-\mathrm{B} 34)^{\wedge} 2\right)$ \\
\hline 40 & $16[\mathrm{~m}]$ & $=\mathrm{SQRT}\left((\mathrm{B} 23-\mathrm{B} 26)^{\wedge} 2+(\mathrm{B} 24-\mathrm{B} 27)^{\wedge} 2+(\mathrm{B} 25-\mathrm{B} 28)^{\wedge} 2\right)$ \\
\hline
\end{tabular}

